\title{
Corticotropin-Releasing Factor Testing Reveals a Dose- Dependent Difference in Methadone Maintained Vs Control Subjects
}

\author{
James H Schluger', Gavin Bart*,', Mark Green', Ann Ho' and Mary Jeanne Kreek' \\ 'The Laboratory of the Biology of Addictive Diseases, The Rockefeller University, New York, NY, USA
}

\begin{abstract}
Opiate addiction is associated with abnormal function of the stress-responsive hypothalamic-pituitary-adrenal (HPA) axis. In general, addiction and withdrawal are associated with abnormal HPA responsivity as demonstrated by baseline, dexamethasone, and metyrapone testing. Following stabilization in methadone maintenance treatment, normalization of HPA axis responsivity is observed. To further investigate HPA axis function associated with heroin addiction and its treatment, saline placebo and human corticotropin-releasing factor (hCRF) were administered intravenously in two doses, one dose lower $(0.5 \mu \mathrm{g} / \mathrm{kg})$ and one dose higher $(2.0 \mu \mathrm{g} / \mathrm{kg})$ than the dose used in standard clinical diagnostics $(100 \mu \mathrm{g})$, to 16 normal male volunteer controls (NV) and eight male stable-dose methadone-maintained former heroin addicts without ongoing drug or alcohol abuse or dependence (MM). Plasma adrenocorticotrophic hormone (ACTH) and cortisol levels were determined at serial time points. There was no difference in hormonal measurements between the two groups following placebo. NV as well as MM displayed a dose-response effect in plasma ACTH and cortisol levels. MM displayed a significantly greater increase in plasma ACTH levels than the NV following high-dose but not low-dose hCRF $(p<0.05)$. There was no significant difference in plasma cortisol levels between the two groups following high-dose hCRF. Thus, despite earlier documented normalization of behavioral function and of several measures of neuroendocrine function during long-term methadone maintenance, some abnormalities in HPA axis responsivity that may be a consequence of heroin exposure, or that may have existed prior to the addiction, can persist during stable methadone treatment.

Neuropsychopharmacology (2003) 28, 985-994, advance online publication, 26 March 2003; doi: I 0. I038/sj.npp. I 300 I 56
\end{abstract}

Keywords: corticotropin-releasing factor (CRF); methadone; addiction; HPA axis; ACTH; cortisol

\section{INTRODUCTION}

Drug addictions represent complex syndromes whose etiologies and natural histories are multidetermined. Factors that contribute to the development and course of addictive diseases include properties of specific drugs of abuse, characteristics of vulnerable individuals, as well as genetic, early developmental, and environmental influences. Our group and others have hypothesized that alterations in responsivity to stress and stressors that may similarly have roots in genetic, developmental, environmental, and also drug-induced factors are integral to the vulnerability to, acquisition and maintenance of, relapse to, and treatment of heroin addiction (Kreek, 1972, 1973a, 1996; Cushman Jr and Kreek, 1974; Wand et al, 2002). The hypothalamicpituitary-adrenal (HPA) axis and its constituent hormones,

\footnotetext{
*Correspondence: G Bart, The Laboratory of the Biology of Addictive Diseases, The Rockefeller University, 1230 York Avenue, New York, NY I002I-6399, USA, Tel: + I 212327 8248, Fax: + I 2123277023 , E-mail: bartg@rockefeller.edu

Received 20 August 2002; revised 12 November 2002; accepted 17 December 2002

Online publication: 08 January 2003 at http://www.acnp.org/citations/ Nppol0803453
}

corticotropin-releasing factor (CRF), adrenocorticotrophic hormone (ACTH), and cortisol, are integral to mammalian stress responsivity. The later two hormones, ACTH and cortisol, are easily measured in the peripheral blood of human subjects and serve as markers of HPA axis function and stress responsivity.

Heroin addicts show alterations in HPA and hypothalamic-pituitary-gonadal axis hormones during active cycles of addiction. More specifically, plasma levels of the HPA axis hormones ACTH and cortisol are reduced during active heroin addiction. Following stabilization with adequate dosages of methadone (80-120 mg), these hormone levels have been observed to return to normal (Kreek, 1972, 1973a; Cushman Jr and Kreek, 1974; Kreek et al, 1983).

Specific tests of HPA axis integrity support the observed disruption in the HPA axis function during cycles of active addiction with normalization of function associated with clinical stabilization. Although major depression has also been associated with altered HPA axis responsivity to neuroendocrine probes such as dexamethasone, depressive symptomatology in methadone-maintained subjects has not been associated with failure to normalize HPA axis response to standard 1 or $2 \mathrm{mg}$ doses of dexamethasone following methadone dose stabilization (Kreek, 1972). Similarly, 
responses to other probes of HPA axis function, such as ACTH infusion or metyrapone (an oral 11- $\beta$-hydroxylase inhibitor that blocks the final step in cortisol synthesis in the adrenal glands) testing have been found to be within normal limits in stabilized methadone-maintained subjects (Kreek, 1972, 1973a; Cushman Jr and Kreek, 1974; Kreek et al, 1984). In recent studies, we have also shown normal HPA response to metyrapone in stable-dose methadone-maintained subjects but not in methadone-maintained subjects with ongoing cocaine dependence (Schluger et al, 2001).

Studies of the opioid receptor antagonist naloxone have shown increased levels of ACTH and cortisol in normal volunteer subjects (Volavka et al, 1979, 1980; Schluger et al, 1998). Other antagonists (naltrexone and nalmefene) with different affinities for the $\mu-, \kappa-$, and $\delta$-opioid receptors also increase ACTH and cortisol (Mendelson et al, 1986; Schluger et al, 1998). These studies and those performed in drug-free former heroin addicts not in methadone maintenance that show increased sensitivity to the HPA effects of opioid antagonists (Kosten et al, 1986a,b) demonstrate the importance of the endogenous opioid system in modulating HPA axis responsivity.

In addition to alterations in endogenous opioid control of HPA axis function, evidence has accumulated to indicate that alterations in CRF signaling, an integral component of HPA axis activity, as well as a component of an extrahypothalamic system, is involved in the pathophysiology of addiction (Kreek and Koob, 1998). For example, several animal models have shown that CRF administration precipitates stress-induced relapse whereas CRF receptor antagonists inhibit stress-induced relapse (for recent reviews, see Koob, 1999; Sarnyai et al, 2001). Extrahypothalamic sites are hypothesized to mediate the effects of CRF in these animal models. However, with respect to HPA axis activity, we have recently shown that alcoholics seek HPA activation and that this activation is achieved with lower alcohol consumption following naltrexone but not placebo administration (O'Malley et al, 2002).

To date, CRF testing has not been reported in persons actively addicted to heroin or in former heroin addicts in methadone maintenance. The present study was performed to use this probe to extend studies of HPA axis integrity in former heroin addicts on stable-dose methadone maintenance who have no ongoing drug or alcohol abuse.

\section{METHODS}

\section{Subjects and Methods}

The study was approved by the Institutional Review Board of The Rockefeller University Hospital General Clinical Research Center (NIH-GCRC) and performed in accordance with the Helsinki Declaration of 1975. Written informed consent was obtained prior to participation; confidentiality was strictly maintained. Normal volunteers were recruited from the local community by word of mouth and by advertisement. Stable methadone-maintained subjects (former opiate addicts without current drug or alcohol comorbidities) were recruited from local methadone maintenance clinics. All subjects were evaluated by laboratory personnel, consisting of registered nurses, internists, and psychiatrists trained in addiction medicine. Subjects were initially screened for the study by phone contact with a registered nurse. Evaluation for medical and psychiatric inclusion and exclusion criteria were made by an internist or psychiatrist using clinical interview, physical exam, and review of laboratory and corroborative data. Evaluations included general medical, psychiatric, and substance abuse histories, physical examination, EKG, and laboratory testing including complete blood cell count, serum electrolytes, creatinine, blood urea nitrogen, liver function tests, thyroid function tests, hepatitis A, B, and C serologies, VDRL, and urinalysis. Subjects recruited from methadone clinics gave consent for the investigators to speak with their counselors so that histories could be verified. Since HIV-1 infection is known to alter specifically the neuroendocrine systems under study, subjects were counseled about, and gave informed consent for, HIV testing. Urine was collected on each of the outpatient visits and on a 24-h basis during inpatient studies. Aliquots of urine were tested daily, both during the screening process and during the inpatient stay, for the presence of mixed opioids, methadone, cocaine, cannabinoids, or benzodiazepines. Subjects were enrolled in the study and allowed to remain in the study only if outpatient and inpatient urine toxicology results were negative for all drugs (except methadone in the methadone-maintained group).

In order to minimize any possible variance in hormone levels owing to gender, only male subjects were included in the current study. The study population consisted of two groups: stable-dose methadone-maintained former heroin addicts without ongoing drug or alcohol abuse or dependence and no DSM-IV Axis I diagnosis other than opiate dependence (methadone group: $n=8$ ), ages $21-55$ years (mean: 36.8 years; SD 14.3), including six smokers and two nonsmokers, and normal healthy volunteers without DSMIV Axis I diagnoses (control group: $n=16$ ), ages 20-42 (mean: 30.2 years; SD 6.2), including six smokers and 10 nonsmokers. Illicit drug use or alcohol use did not reach DSM-IV criteria for abuse or dependence in any of the subjects. Subjects were free of significant active medical problems including HIV seropositivity, were not taking any prescription medications (other than methadone for the methadone group), and were not regularly using over-thecounter medications or herbal preparations. All former heroin addicts were in a methadone maintenance treatment program for heroin dependence for a minimum of 6 months, and stabilized on the same dose of methadone for the at least 1 month prior to the study (methadone group: mean methadone dose $72.5 \mathrm{mg} /$ day, range $20-100 \mathrm{mg} /$ day). All subjects were medication free (except methadone in the methadone group) for at least 7 days prior to the study.

Subjects were admitted to the inpatient unit one evening prior to the testing days. In most cases testing was completed on 3 consecutive days. In some cases, testing was carried out during separate closely scheduled admissions in order to accommodate time constraints of subjects. Subjects fasted at least $9 \mathrm{~h}$ prior to the beginning of a testing day and were allowed to eat only after the first $2 \mathrm{~h}$ of testing had elapsed. Test substances were administered through, and blood samples were withdrawn from, an indwelling intravenous catheter (Intracath), inserted at least an hour prior to the beginning of testing. In some cases, a functioning catheter from the previous day was used. Total 
blood volume sampled, including that taken during screening and testing, did not exceed $550 \mathrm{ml}$.

Between 9:00 and 9:30 am on each of the 3 testing days, a normal saline placebo $(0 \mu \mathrm{g} / \mathrm{kg}$ human corticotropinreleasing factor (hCRF)), low-dose hCRF $(0.5 \mu \mathrm{g} / \mathrm{kg})$, or high-dose hCRF $(2.0 \mu \mathrm{g} / \mathrm{kg})$ was administered in a single blind fashion via 2-min intravenous infusion. To minimize risk, a dose run-up schedule was employed at the request of the Food and Drug Administration. Each subject received a placebo, the low dose of hCRF, and the high dose of hCRF, on separate days. Each subject served as his own control. Methadone-maintained subjects received their daily dose of methadone $60 \mathrm{~min}$ after the test medication was administered (peak plasma level 2-4h after methadone administration with maintained plateau $22-26 \mathrm{~h}$ following methadone administration) (Kling et al, 2000). Subjects who smoked were not permitted to do so from $60 \mathrm{~min}$ prior to and until $4 \mathrm{~h}$ following hCRF or placebo infusion.

Plasma ACTH and cortisol levels were determined in blood samples drawn at sequential time points. Time points started 10 min prior to test substance administration, then at time zero (immediately prior to test substance administration), then at $10,20,30,40,50,60,75,90,120,150,180$, and $240 \mathrm{~min}$ following hCRF or placebo administration. Blood was drawn into both sodium EDTA vacutainers and plain vacutainers, and immediately placed on ice. Samples were stored on ice for up to $40 \mathrm{~min}$ until centrifuged at $4{ }^{\circ} \mathrm{C}$ at $3000 \mathrm{rpm}$ for $5 \mathrm{~min}$. Plasma was then removed, aliquoted and stored at $-40^{\circ} \mathrm{C}$ until assayed. ACTH and cortisol levels were determined in duplicate by RIA procedures, with slight modifications (ACTH - Nichols Institute, San Juan Capistrano, California; Cortisol-Diagnostic Products Corporation, Los Angeles, California). ACTH intra- and interassay coefficients of variation were 9.4 and $15.1 \%$, respectively. Cortisol intra- and interassay coefficients of variation were 2.5 and $6.0 \%$, respectively.

\section{Statistical Analysis}

Area under the curve (AUC) from 0 to 90 min after each dose of hCRF was calculated for each subject. First, the dose-response effect in normal volunteers (control group) was assessed by a one-way ANOVA of AUCs for each hormone followed by Newman-Keuls post hoc tests. Then to examine the possible differences between the control group and the methadone group, a two-way ANOVA of AUCs, Group $\times$ Dose, with repeated measures on the last factor was conducted for each hormone, with planned comparisons between groups after the 0 dose placebo and after the highest dose used in this study, $2.0 \mu \mathrm{g} / \mathrm{kg}$ hCRF. Finally, to compare the difference between the control group and the methadone group in the magnitude of response to hCRF for each hormone, the change from placebo AUC of each subject after the 0.5 and $2.0 \mu \mathrm{g} / \mathrm{kg}$ dose hCRF was calculated and examined by a two-way ANOVA with a planned comparison at the $2.0 \mu \mathrm{g} / \mathrm{kg}$ dose.

Preliminary analyses of each hormone, three-way ANOVAs of Group (control group, methadone group) $\times$ Smoking Status (Yes, No) $\times$ Dose $(0,0.5,2.0 \mu \mathrm{g} / \mathrm{kg}$ hCRF), showed no significant main effect of Smoking Status, so the factor for Smoking Status was not used in subsequent analyses. However, since the methadone group had proportionately more smokers (six of eight subjects) than the control group (six of 16 subjects), when a significant difference between groups was found, an ANOVA was conducted on the smoking subset to verify the group difference in hormonal response.

\section{RESULTS}

Plasma levels of ACTH and cortisol for each group from immediately before to $90 \mathrm{~min}$ after administration of each dose of hCRF $(0,0.5$, or $2.0 \mu \mathrm{g} / \mathrm{kg})$ are shown in Figure 1 expressed as mean \pm SEM. By the 90 -min time point, both the ACTH and cortisol values of each group were at 0 dose (placebo) levels; therefore, time points beyond 90-min were excluded from the analysis.

\section{Dose Response in Normal Volunteers}

The dose response of the control group to hCRF expressed as 90-min AUCs of ACTH and of cortisol are shown in Figure 2. ANOVA of ACTH AUCs showed a significant effect of hCRF dose, $\mathrm{F}(2,30)=18.97, p<0.00001$. NewmanKeuls post hoc tests showed that ACTH response to $0.5 \mu \mathrm{g} /$ $\mathrm{kg}$ hCRF was significantly higher than the placebo 0 dose condition $(p<0.002)$, and the response to the higher dose $2.0 \mu \mathrm{g} / \mathrm{kg}$ was significantly higher than that to the $0.5 \mu \mathrm{g} / \mathrm{kg}$ dose $(p<0.02)$. There was also a significant effect of hCRF dose in AUCs of cortisol, $\mathrm{F}(2,30)=11.66, p<0.0002$, but the pattern was different. Both doses significantly raised plasma cortisol over levels in the 0 dose placebo condition, the $0.5 \mu \mathrm{g} / \mathrm{kg}$ dose $(p<0.001)$, and the $2.0 \mu \mathrm{g} / \mathrm{kg}$ dose $(p<0.0005)$, but the response to the $2.0 \mu \mathrm{g} / \mathrm{kg}$ dose was not significantly greater than that to the $0.5 \mu \mathrm{g} / \mathrm{kg}$ dose.

\section{Difference between Normal Volunteer and Methadone- Maintained Subjects}

An ANOVA of ACTH AUCs, Group $\times$ Dose with repeated measures on the last factor, showed no significant main effect of subject group, $\mathrm{F}(1,22)<1$, a significant effect of Dose, $F(2,44)=34.08, \quad p<0.000001$, and a significant Group $\times$ Dose interaction, $F(2,44)=5.34, p<0.01$ (see Figure 3). Planned comparisons showed that while there was no difference between subject groups in the 0 dose, placebo condition, the methadone group had a significantly greater ACTH response to the $2.0 \mu \mathrm{g} / \mathrm{kg}$ dose than did the control group.

ANOVA of cortisol AUCs also did not show a significant subject group difference, $\mathrm{F}(1,22)=1.18$ (see Figure 3 ). And while there was a significant main effect of hCRF Dose, $\mathrm{F}(2,44)=6.98, \quad p<0.005$, there was no significant Group $\times$ Dose interaction, $\mathrm{F}(2,44)<1$.

\section{Contrast of ACTH with Cortisol Responses to hCRF}

Another way to examine the difference in the response to different doses of hCRF is to examine the increase in AUC of each subject after each dose over his placebo value. Mean group increases over placebo AUCs of ACTH and cortisol $(+$ SEM) are shown in Figure 4 . When the results are expressed in this way, ANOVA of the ACTH increases showed a significant main effect of subject group, 

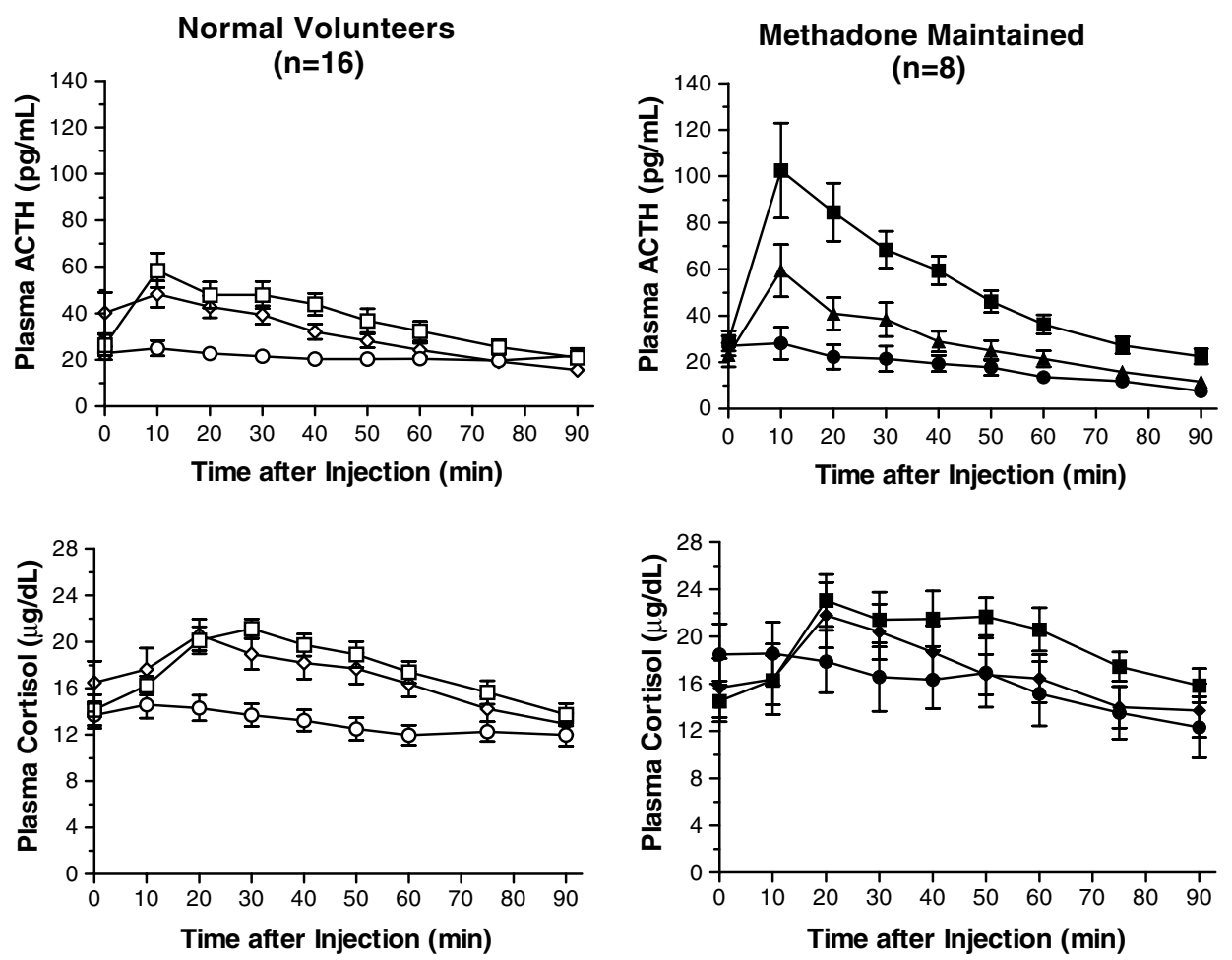

Figure I Plasma levels of the control group ( $N V, n=16)$ from just before to $90 \mathrm{~min}$ after injection of $0,0.5$, or $2.0 \mu \mathrm{g} / \mathrm{kg} \mathrm{hCRF}$ are shown on the left side, $\mathrm{ACTH}$ on the top and cortisol below, with plasma levels of methadone-maintained subjects $(M M, n=8)$ shown on the right, expressed as mean \pm SEM

$\mathrm{F}(1,22)=4.78, p<0.05$, a significant main effect of Dose, $\mathrm{F}(1,22)=17.93, p<0.0005$, and a significant Group $\times$ Dose interaction, $\mathrm{F}(1,22)=5.62, p<0.05$. Planned comparison of groups at the high dose showed a significant difference, $p<0.05$. (This pattern was mirrored in the results of an ANOVA of the smoker subset: there was a significant main effect of Group, $\mathrm{F}(1,10)=5.55, p<0.05$, a significant main effect of Dose, $\mathrm{F}(1,10)=14.63, p<0.005$, and a planned comparison at the $2.0 \mu \mathrm{g} / \mathrm{kg}$ dose hCRF showed that methadone group responses were greater than those of control group, $p=0.053$.) Thus, while there was no difference between the methadone group and the control group in the ACTH response to the low dose, $0.5 \mu \mathrm{g} / \mathrm{kg}$ hCRF, the methadone group showed significantly greater elevation than the control group at the $2.0 \mu \mathrm{g} / \mathrm{kg}$ dose. This pattern was not seen in cortisol responses, where there was no significant interaction and, if anything, the cortisol of the methadone group appeared to be (but was not significantly) lower than that of the control group.

\section{DISCUSSION}

The first evidence that HPA axis function is affected by administration of short-acting opiates in humans was reported in 1958 by Eisenman who observed that urinary levels of 17-ketosteroids were reduced during cycles of chronic morphine administration (Eisenman et al, 1958, 1961, 1969). Subsequently, studies of heroin addiction and its treatment have indicated that active use of heroin is associated with HPA axis suppression, early abstinence with HPA axis activation, and normalization of HPA axis function with long-term abstinence from heroin utilizing with long-acting opioid pharmacotherapy (Kreek, 1972, 1973a, 1978; Cushman Jr and Kreek, 1974; Stimmel and Kreek, 1975).

Methadone, a synthetic exogenous opiate with a long halflife in humans (over $24 \mathrm{~h}$ for the racemic mixture used in pharmacotherapy), provides a steady-state occupancy of $\mu$ opiate receptors in the CNS when administered chronically (Inturrisi and Verebely, 1972; Dole and Kreek, 1973; Kreek, 1973b; Kreek et al, 1979; Kling et al, 2000). As originally hypothesized by this group (Dole et al, 1966), and demonstrated by this group and others, the steady-state activity of methadone allows normalization of the altered HPA axis responsivity seen in opiate addiction (Kreek, 1972, 1973a; Cushman Jr and Kreek, 1974; Kreek et al, 1983, 1984). Positron emission tomography (PET) studies performed in stable-dose methadone-maintained subjects have shown that only $19-32 \%$ of $\mu$-opiate receptors are occupied during steady-state methadone therapy thereby allowing the remaining receptors to function in their normal physiologic capacity modulating pain and analgesia, immune function, and the HPA axis (Kling et al, 2000). The return of normal HPA axis responsivity during stable-dose methadone maintenance is likely due to this and, in part, to the normalization of opioidergic tone evidenced by the normalization of HPA responsivity to the removal of the other, and major, modulator of HPA axis response, glucocorticoid negative feedback, using metyrapone (an inhibitor of cortisol synthesis) (Kreek, 1972, 1973a; Kreek et al, 1984; Kennedy et al, 1990; Schluger et al, 2001). Further supporting the hypothesis of normalized opioidergic tone in methadone maintenance, former heroin addicts in long- 

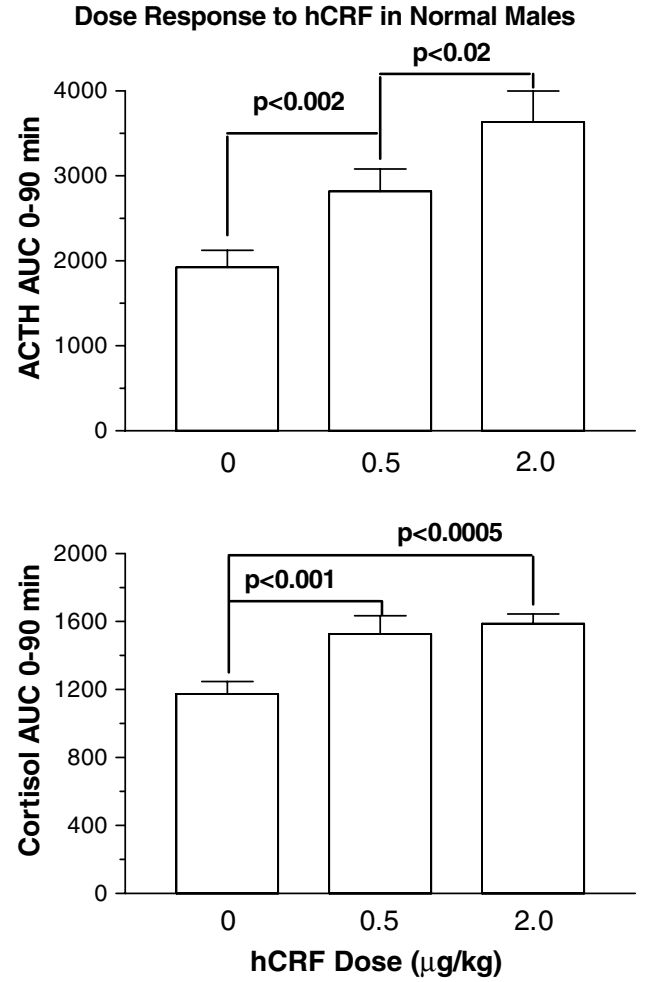

Figure 2 The dose response of the control (NV) to hCRF expressed as 90-min AUCs of ACTH and of cortisol are shown. ANOVA showed a significant effect of hCRF dose on each hormone. Newman-Keuls post hoc tests showed that ACTH response to $0.5 \mu \mathrm{g} / \mathrm{kg}$ hCRF was significantly higher than the placebo 0 dose condition and the response to the $2.0 \mu \mathrm{g} / \mathrm{kg}$ dose was significantly higher than that to the $0.5 \mu \mathrm{g} / \mathrm{kg}$ dose. There was a different pattern in cortisol response: both doses significantly raised plasma cortisol over levels in the 0 dose, placebo condition, but the response to the $2.0 \mu \mathrm{g} / \mathrm{kg}$ dose was not significantly greater than that to the $0.5 \mu \mathrm{g} / \mathrm{kg}$ dose.

term abstinence without methadone pharmacotherapy have increased HPA responsivity to metyrapone testing (Kreek et al, 1984).

While the influence of the endogenous opioid system on HPA axis responsivity in methadone maintenance may be normalized, it is not yet known whether all components of the HPA axis such as the release and levels of CRF are also normalized with methadone maintenance treatment. Since its initial characterization by Vale et al (1981), several studies have shown that CRF is expressed throughout the mammalian brain. Hypothalamic release of CRF from the paraventricular nucleus activates anterior pituitary production of proopiomelanocortin (POMC), which is rapidly processed into several peptide fragments, many of which are biologically active. These include, in equimolar ratio, ACTH and beta-lipotropin, which is further processed to beta-endorphin. Animal model studies have suggested that extrahypothalamic sites of CRF activity affect anxiety-like behaviors, food intake, arousal, memory, and learning (Sutton et al, 1982; Ehlers et al, 1983; Krahn et al, 1986; De Souza et al, 1987; Radulovic et al, 1999).

Following intravenous CRF administration, a doseresponse effect of ACTH and cortisol is seen in humans. In humans, ovine CRF (oCRF), which is the commercially available CRF used in clinical diagnostics, has a longer plasma half-life (73 min) than human CRF (hCRF) $(27 \mathrm{~min}$ ) (eg Saphier et al, 1992). Dose-response studies of oCRF, which differs by 7 amino acids from hCRF, using doses of $0.001-30 \mu \mathrm{g} / \mathrm{kg}$ (Orth et al, 1983) and hCRF using doses of $0.01-5 \mu \mathrm{g} / \mathrm{kg}$ (Schurmeyer et al, 1984) have demonstrated an apparent maximal response in cortisol at doses above 3.0 and $1.0 \mu \mathrm{g} / \mathrm{kg}$, respectively. However, neither of these studies, nor any other published dose-response studies of oCRF or hCRF, achieved a maximal response (ie no plateau reached) in ACTH to the highest administered doses of CRF. We studied the effects of hCRF because it is the natural peptide and, upon intravenous administration, mimics the brevity of endogenous pulses of ACTH and cortisol release (Schurmeyer et al, 1984; Avgerinos et al, 1986).

In this study of 16 male normal volunteers and eight male methadone-maintained patients, a dose-response effect was shown in plasma ACTH and cortisol levels following 0.5 and $2.0 \mu \mathrm{g} / \mathrm{kg}$ hCRF. The response of ACTH to $2.0 \mu \mathrm{g} / \mathrm{kg}$ was significantly greater in the methadone group than in the control group. In this study, we found a normal response in both the methadone group and the control group to a lower than standard dose of hCRF $(0.5 \mu \mathrm{g} / \mathrm{kg})$. Why a significantly greater increase in ACTH following the much higher dose of $2.0 \mu \mathrm{g} / \mathrm{kg}$ hCRF was observed in the successfully treated methadone group as contrasted to the control group remains unclear. As there are no other studies of CRF in humans with active heroin addiction or in former opiate addicts in abstinence-based or long-acting opioid pharmacotherapy-based treatment, it is not known whether ACTH response to similar CRF testing in these groups would be low, high, or normal.

Disease states affecting the HPA axis (eg cortisolproducing adrenal tumor, panic disorder, and subtypes of depression) in which ACTH and cortisol response to CRF is lower than in controls show normalization of response to a standard $(100 \mu \mathrm{g}$ or $1.0 \mu \mathrm{g} / \mathrm{kg})$ dose of CRF following successful surgical and or pharmacological treatment (Muller et al, 1986; Curtis et al, 1997; Zobel et al, 1999). It is not known whether these responses would remain normal following higher doses of CRF.

Nonalcoholic men with a family history of alcoholism (FHP) were found to have lower peak ACTH levels following $1.0 \mu \mathrm{g} / \mathrm{kg}$ oCRF than men without a family history of alcoholism (FHN) (Waltman et al, 1994). Following oral alcohol administration, the FHN group experienced a blunting in ACTH response to oCRF whereas the FHP group did not. There was no difference between the two groups in cortisol response to oCRF with or without alcohol administration. In alcoholic subjects, acute withdrawal (12$72 \mathrm{~h}$ after last alcohol use) and medium-term abstinence (13-42 days after last alcohol use) are both associated with decreased ACTH response following $100 \mu \mathrm{g}$ hCRF (von Bardeleben et al, 1989; Hundt et al, 2001). While these findings are similar to those seen in major depression, the authors did not control for affective states.

It has been proposed that the anxiety that characterizes withdrawal from drug and/or alcohol abuse and addiction may be, in part, related to the action of CRF-producing neurons in the hypothalamus and, also, the central nucleus of the amygdala (Richter et al, 1995; Richter and Weiss, 

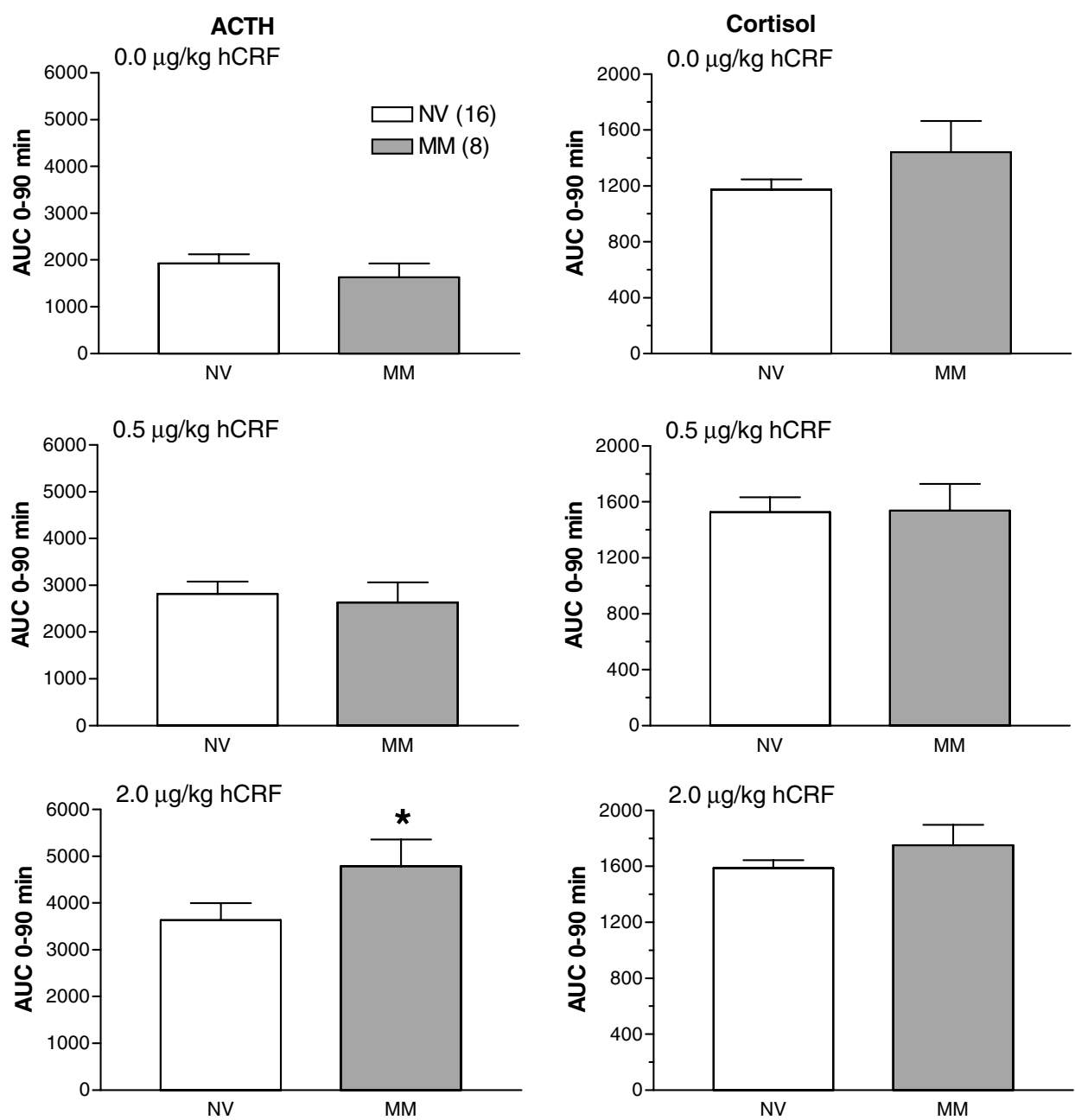

Figure 3 Left: the mean ( + SEM) 90-min AUC of ACTH of each group after each dose is shown. A Group $\times$ Dose ANOVA showed a significant effect of Dose, and significant Group $\times$ Dose interaction. Planned comparisons showed that while there was no difference between subject groups in the 0 dose, placebo condition, the methadone group (MM) had a significantly greater $(* p<0.05)$ ACTH response to the $2.0 \mu g / \mathrm{kg}$ dose than did the control group (NV). Right: the mean (+SEM) 90-min AUC of cortisol of each group after each dose is shown. While there was a significant main effect of hCRF Dose on cortisol levels, no significant differences between groups were found.

1999). In animal models, suppression of CRF in the amygdala by direct infusion of the CRF antagonist alphahelical CRF (9-41) attenuates the aversive consequences of opiate antagonist-induced morphine withdrawal (Heinrichs et al, 1995). It has also been shown that stress (ie maternal deprivation prior to weaning) produces effects on CRF neural systems in both the CNS and pituitary including increases in CRF levels in the median eminence of the hypothalamus and increases in specific binding of CRF in extrapituitary sites (Plotsky and Meaney, 1993; Ladd et al, 1996). Persistent elevations in cerebrospinal fluid levels of CRF have been shown in nonhuman primates exposed to early life stressors (Coplan et al, 1996) and humans with post-traumatic stress disorder (Bremner et al, 1997).

Antagonists of CRF activity attenuate the anxiogenic effects of CRF. These include CRF antiserum, nonspecific antagonists of CRF receptors, and CRFR1-specific peptidic and nonpeptidic antagonists. Mice lacking the CRF gene do, however, continue to display stress-induced behavior that is attenuated by a CRFR1 antagonist, a finding that may suggest the presence of a ligand other than CRF (such as urocortin or an undefined CRF-like agonist) that is active at the CRFR1 receptor (Weninger et al, 1999). As anticipated, mice lacking the CRFR1 gene show an impaired stress response including impaired ACTH and corticosterone release (Smith et al, 1998; Timpl et al, 1998; Lee et al, 2001; Bale et al, 2002). Interestingly, however, basal levels of ACTH and corticosterone were unaffected in CRFR1 knockout mice (Timpl et al, 1998).

In human studies, during acute, subacute, and chronic self-administration of drugs of abuse such as opiates, cocaine, and alcohol, evolving changes with time of exposure are observed in HPA axis stress response, hormone production, and also gene expression (Kreek, 1972; Gianoulakis et al, 1996; Mendelson et al, 1998; Wand et al, 1998; Schluger et al, 2001; Schuckit et al, 2001; O'Malley et al, 2002). In animal models, for instance, decreased hypothalamic CRF mRNA was found following 14-day binge pattern cocaine in rats; however, levels returned to normal 10 days following the final cocaine administration (Zhou et al, 1996a). While acute and subacute morphine administration in rats causes HPA axis 

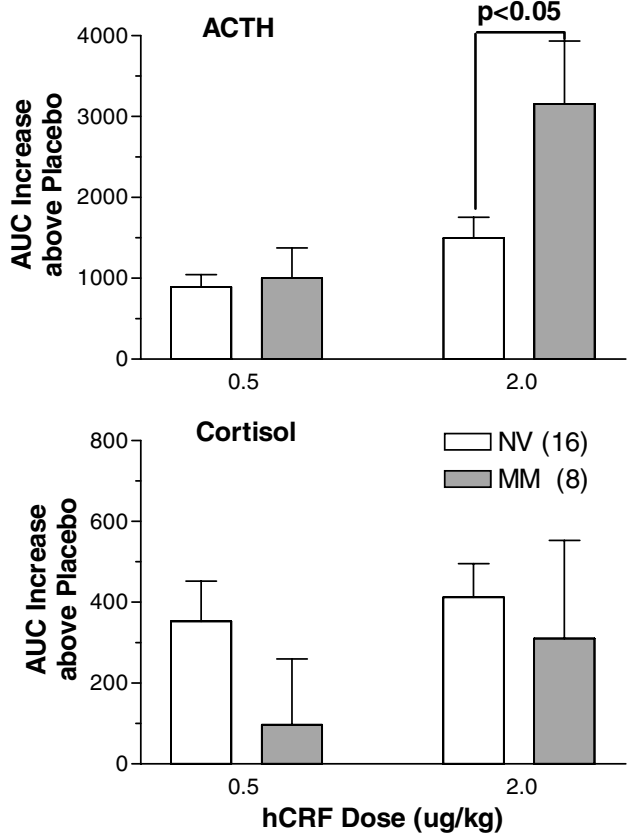

Figure 4 The mean (+SEM) increase of AUCs of ACTH and cortisol over placebo are shown. ANOVA of the ACTH increases showed a significant main effect of subject group, of Dose, and a significant Group $\times$ Dose interaction. Planned comparison at the $2.0 \mu \mathrm{g} / \mathrm{kg}$ dose showed that the response of the methadone group (MM) was significantly higher than that of the control group (NV).

activation including an elevation in hypothalamic CRF that is blocked by CRF antiserum (Buckingham, 1982; Nikolarakis et al, 1987), chronic administration does not (Buckingham and Cooper, 1984; Ignar and Kuhn, 1990). Acute morphine administration in rats undergoing water restriction stress blunts the increase in hypothalamic CRF mRNA seen in the placebo-treated water-restricted rats (Zhou et al, 1999). Furthermore, this blunting reduces hypothalamic CRF mRNA levels to those seen in nonstressed salinetreated rats. Methadone, delivered at steady state via pump, does not change the levels of CRF, CRF-R1 receptor, or POMC (Zhou et al, 1996b). Binge pattern alcohol administration to rats causes a decrease in hypothalamic CRF mRNA levels (Zhou et al, 2000).

CRF may also contribute to stress-induced relapse to drug seeking in heroin, cocaine, and ethanol-seeking rats (Shaham et al, 1997, 1998; Erb et al, 1998; Le et al, 2000). Stress-induced reinstatement of heroin self-administration is partially mimicked by central administration of CRF and is likely mediated through the CRFR1 receptor (Shaham et al, 1997; Erb et al, 1998; Lu et al, 2000, 2001). The effect of $\mathrm{CRF}$ antagonist attenuation of drug reinstatement may be related to the removal of ACTH-mediated corticosterone release. In fact, corticosterone administration facilitates, whereas its removal, either surgically by adrenalectomy or pharmacologically with metyrapone or ketaconazole, lowers, cocaine self-administration (Goeders and Guerin, 1996; Erb et al, 1998; Goeders et al, 1998; Mantsch and Goeders, 1999).

Our finding of a significant increase in ACTH response to the higher, $2.0 \mu \mathrm{g} / \mathrm{kg}$, dose hCRF in the methadone group compared to the control group may indicate increased pituitary sensitivity to CRF in the methadone group. This effect is likely at the level of the pituitary outside of the blood-brain barrier, as peripherally administered hCRF has poor central penetrance (Martins et al, 1996). Whether this effect is also because of hCRF action in the hypothalamus is unknown.

Changes within the endogenous opioid system that predate opiate addiction and/or persist following its treatment may contribute to these findings. We have demonstrated in a cellular model that a high allelic frequency (10.5\% across mixed ethnic/cultural groups) single nucleotide polymorphism (SNP) in the $\mu$-opiate receptor gene confers a three-fold increase in endogenous ligand binding and a three-fold increase in agonist-induced activation of $\mathrm{G}$ protein-coupled potassium channels (Bond et al, 1998). We, and others, have hypothesized that this (A118G) and other polymorphisms of genes could contribute to the protection from, or vulnerability to addiction (Bergen et al, 1997; Berrettini et al, 1997; Bond et al, 1998; Sander et al, 1998; Gelernter et al, 1999; LaForge et al, 2000; LaForge and Kreek, 2000; Franke et al, 2001; Szeto et al, 2001; Chen et al, 2002). Recently, Wand et al (2002) have demonstrated that heterozygous carriers of the A118G polymorphism have a greater response of ACTH following the intravenous administration of the $\mu$-opiate antagonist naloxone. Further studies of CRF are needed including studies in female subjects and studies performed during other stages of opiate addiction and its treatment. Studies of the endogenous opioid system and the variance of genes of the opioid system and of the HPA axis are also needed. A better understanding of these interactions could assist in the development of future pharmacotherapies for opiate and other addictions.

\section{ACKNOWLEDGMENTS}

This work was supported in part by grants DA-P60-05130, DA00049, and a General Clinical Research Center grant (M01-RR00102) from the National Center for Research Resources, at the National Institutes of Health. We gratefully acknowledge the assistance of Dr Pauline McHugh, Dr Lisa Borg, Abena Amoah, Wan-Xin Feng, David Fussell, Sara Handy, Lauren Hofmann, and Benjamin Seides.

\section{REFERENCES}

Avgerinos PC, Schurmeyer TH, Gold PW, Tomai TP, Loriaux DL, Sherins RJ et al (1986). Pulsatile administration of human corticotropin-releasing hormone in patients with secondary adrenal insufficiency: restoration of the normal cortisol secretory pattern. J Clin Endocrinol Metab 62: 816-821.

Bale TL, Picetti R, Contarino A, Koob GF, Vale WW, Lee KF (2002). Mice deficient for both corticotropin-releasing factor receptor 1 (CRFR1) and CRFR2 have an impaired stress response and display sexually dichotomous anxiety-like behavior. $J$ Neurosci 22: 193-199.

Bergen AW, Kokoszka J, Peterson R, Long JC, Virkkunen M, Linnoila $\mathrm{M}$ et al (1997). Mu opioid receptor gene variants: lack of association with alcohol dependence. Mol Psychiatry 2: 490494.

Berrettini WH, Hoehe MR, Ferraro TN, DeMaria PA, Gottheil E (1997). Human mu opioid receptor gene polymorphisms and vulnerability to substance abuse. Addict Biol 2: 303-308. 
Bond C, LaForge KS, Tian M, Melia D, Zhang S, Borg L et al (1998). Single-nucleotide polymorphism in the human mu opioid receptor gene alters beta-endorphin binding and activity: possible implications for opiate addiction. Proc Natl Acad Sci USA 95: 9608-9613.

Bremner JD, Licinio J, Darnell A, Krystal JH, Owens MJ, Southwick SM et al (1997). Elevated CSF corticotropin-releasing factor concentrations in posttraumatic stress disorder. Am J Psychiatry 154: 624-629.

Buckingham JC (1982). Secretion of corticotrophin and its hypothalamic releasing factor in response to morphine and opioid peptides. Neuroendocrinology 35: 111-116.

Buckingham JC, Cooper TA (1984). Differences in hypothalamopituitary-adrenocortical activity in the rat after acute and prolonged treatment with morphine. Neuroendocrinology 38: 411-417.

Chen ACH, LaForge KS, Ho A, McHugh PF, Kellogg S, Bell K et al (2002). A potentially functional polymorphism in the promoter region of prodynorphin gene may be associated with protection against cocaine dependence or abuse. Am J Med Genet 114: 429435.

Coplan JD, Andrews MW, Rosenblum LA, Owens MJ, Friedman S, Gorman JM et al (1996). Persistent elevations of cerebrospinal fluid concentrations of corticotropin-releasing factor in adult nonhuman primates exposed to early-life stressors: implications for the pathophysiology of mood and anxiety disorders. Proc Natl Acad Sci USA 93: 1619-1623.

Curtis GC, Abelson JL, Gold PW (1997). Adrenocorticotropic hormone and cortisol responses to corticotropin-releasing hormone: changes in panic disorder and effects of alprazolam treatment. Biol Psychiatry 41: 76-85.

Cushman Jr P, Kreek MJ (1974). Some endocrinologic observations in narcotic addicts. In: Zimmermann E, George R (eds). Narcotics and the Hypothalamus. Raven Press: New York. pp 161-173.

De Souza EB, Whitehouse PJ, Price DL, Vale WW (1987). Abnormalities in corticotropin-releasing hormone (CRH) in Alzheimer's disease and other human disorders. Ann NY Acad Sci 512: 237-247.

Dole VP, Nyswander ME, Kreek MJ (1966). Narcotic blockade. Arch Intern Med 118: 304-309.

Dole VP, Kreek MJ (1973). Methadone plasma level: sustained by a reservoir of drug in tissue. Proc Natl Acad Sci USA 70: 10.

Ehlers CL, Henriksen SJ, Wang M, Rivier J, Vale W, Bloom FE (1983). Corticotropin releasing factor produces increases in brain excitability and convulsive seizures in rats. Brain Res 278: 332-336.

Eisenman AJ, Fraser HF, Brooks JW (1961). Urinary excretion and plasma levels of 17-hydroxycorticosteroids during a cycle of addiction to morphine. J Clin Endocrinol Metab 132: 226-231.

Eisenman AJ, Fraser HF, Sloan J, Isbell H (1958). Urinary 17ketosteroid excretion during a cycle of addiction to morphine. $J$ Clin Endocrinol Metab 124: 305-311.

Eisenman AJ, Sloan JW, Martin WR, Jasinski DR, Brooks JW (1969). Catecholamine and 17-hydroxycorticosteroid excretion during a cycle of morphine dependence in man. J Psychiatr Res 7: 19-28.

Erb S, Shaham Y, Stewart J (1998). The role of corticotropinreleasing factor and corticosterone in stress- and cocaineinduced relapse to cocaine seeking in rats. J Neurosci 18: 55295536.

Franke P, Wang T, Nothen MM, Knapp M, Neidt H, Albrecht S et al (2001). Nonreplication of association between mu-opioidreceptor gene (OPRM1) A118G polymorphism and substance dependence. Am J Med Genet 105: 114-119.

Gelernter J, Kranzler H, Cubells J (1999). Genetics of two mu opioid receptor gene (OPRM1) exon I polymorphisms: popula- tion studies, and allele frequencies in alcohol- and drugdependent subjects. Mol Psychiatry 4: 476-483.

Gianoulakis C, Krishnan B, Thavundayil J (1996). Enhanced sensitivity of pituitary beta-endorphin to ethanol in subjects at high risk of alcoholism. Arch Gen Psychiatry 53: 250-257.

Goeders NE, Guerin GF (1996). Effects of surgical and pharmacological adrenalectomy on the initiation and maintenance of intravenous cocaine self-administration in rats. Brain Res $\mathbf{7 2 2}$ $145-152$.

Goeders NE, Peltier RL, Guerin GF (1998). Ketoconazole reduces low dose cocaine self-administration in rats. Drug Alcohol Depend 53: 67-77.

Heinrichs SC, Menzaghi F, Schulteis G, Koob GF, Stinus L (1995). Suppression of corticotropin-releasing factor in the amygdala attenuates aversive consequences of morphine withdrawal. Behav Pharmacol 6: 74-80.

Hundt W, Zimmermann U, Pottig M, Spring K, Holsboer F (2001). The combined dexamethasone-suppression/CRH-stimulation test in alcoholics during and after acute withdrawal. Alcohol Clin Exp Res 25: 687-691.

Ignar DM, Kuhn CM (1990). Effects of specific mu and kappa opiate tolerance and abstinence on hypothalamo-pituitaryadrenal axis secretion in the rat. J Pharmacol Exp Ther 255: $1287-1295$.

Inturrisi CE, Verebely K (1972). The levels of methadone in the plasma in methadone maintenance. Clin Pharmacol Ther 13: 633-637.

Kennedy JA, Hartman N, Sbriglio R, Khuri E, Kreek MJ (1990). Metyrapone-induced withdrawal symptoms. $\mathrm{Br} J$ Addict 85: $1133-1140$

Kling MA, Carson RE, Borg L, Zametkin A, Matochik JA, Schluger J et al (2000). Opioid receptor imaging with positron emission tomography and $[(18) \mathrm{F}]$ cyclofoxy in long-term, methadonetreated former heroin addicts. J Pharmacol Exp Ther 295: 10701076.

Koob GF (1999). Stress, corticotropin-releasing factor, and drug addiction. Ann NY Acad Sci 897: 27-45.

Kosten TR, Kreek MJ, Ragunath J, Kleber HD (1986a). A preliminary study of beta endorphin during chronic naltrexone maintenance treatment in ex-opiate addicts. Life Sci 39: 55-59.

Kosten TR, Kreek MJ, Ragunath J, Kleber HD (1986b). Chronic naltrexone effect on cortisol. NIDA Res Monogr 67: 362-365.

Krahn DD, Gosnell BA, Grace M, Levine AS (1986). CRF antagonist partially reverses CRF- and stress-induced effects on feeding. Brain Res Bull 17: 285-289.

Kreek MJ (1972). Medical safety, side effects and toxicity of methadone. Proceedings of the Fourth National Conference on Methadone Treatment. pp 171-174.

Kreek MJ (1973a). Medical safety and side effects of methadone in tolerant individuals. JAMA 223: 665-668.

Kreek MJ (1973b). Plasma and urine levels of methadone: comparison following four medication forms used in chronic maintenance treatment. NY State J Med 73: 2773-2777.

Kreek MJ (1978). Medical complications in methadone patients. Ann NY Acad Sci 311: 110-134.

Kreek MJ (1996). Opiates, opioids and addiction. Mol Psychiatry 1: 232-254.

Kreek MJ, Hachey DL, Klein PD (1979). Stereoselective disposition of methadone in man. Life Sci 24: 925-932.

Kreek MJ, Koob GF (1998). Drug dependence: stress and dysregulation of brain reward pathways. Drug Alcohol Depend 51: 23-47.

Kreek MJ, Ragunath J, Plevy S, Hamer D, Schneider B, Hartman N (1984). ACTH, cortisol and beta-endorphin response to metyrapone testing during chronic methadone maintenance treatment in humans. Neuropeptides 5: 277-278.

Kreek MJ, Wardlaw SL, Hartman N, Raghunath J, Friedman J, Schneider B et al (1983). Circadian rhythms and levels of beta- 
endorphin, ACTH, and cortisol during chronic methadone maintenance treatment in humans. Life Sci 33(Suppl 1): 409-411. Ladd CO, Owens MJ, Nemeroff CB (1996). Persistent changes in corticotropin-releasing factor neuronal systems induced by maternal deprivation. Endocrinology 137: 1212-1218.

LaForge KS, Kreek MJ (2000). Genetic contributions to protection from, or vulnerability to, addictive diseases. NIDA Res Monogr 180: 48.

LaForge KS, Yuferov V, Kreek MJ (2000). Opioid receptor and peptide gene polymorphisms: potential implications for addictions. Eur J Pharmacol 410: 249-268.

Le AD, Harding S, Juzytsch W, Watchus J, Shalev U, Shaham Y (2000). The role of corticotrophin-releasing factor in stressinduced relapse to alcohol-seeking behavior in rats. Psychopharmacology (Berl) 150: 317-324.

Lee S, Smith GW, Vale W, Lee KF, Rivier C (2001). Mice that lack corticotropin-releasing factor (CRF) receptors type 1 show a blunted ACTH response to acute alcohol despite up-regulated constitutive hypothalamic CRF gene expression. Alcohol Clin Exp Res 25: 427-433.

Lu L, Ceng X, Huang M (2000). Corticotropin-releasing factor receptor type I mediates stress-induced relapse to opiate dependence in rats. Neuroreport 11: 2373-2378.

Lu L, Liu D, Ceng X (2001). Corticotropin-releasing factor receptor type 1 mediates stress-induced relapse to cocaine-conditioned place preference in rats. Eur J Pharmacol 415: 203-208.

Mantsch JR, Goeders NE (1999). Ketoconazole blocks the stressinduced reinstatement of cocaine-seeking behavior in rats: relationship to the discriminative stimulus effects of cocaine. Psychopharmacology (Berl) 142: 399-407.

Martins JM, Kastin AJ, Banks WA (1996). Unidirectional specific and modulated brain to blood transport of corticotropinreleasing hormone. Neuroendocrinology 63: 338-348.

Mendelson JH, Mello NK, Cristofaro P, Skupny A, Ellingboe J (1986). Use of naltrexone as a provocative test for hypothalamicpituitary hormone function. Pharmacol Biochem Behav 24: 309313.

Mendelson JH, Sholar M, Mello NK, Teoh SK, Sholar JW (1998). Cocaine tolerance: behavioral, cardiovascular, and neuroendocrine function in men. Neuropsychopharmacology 18: 263-271.

Muller OA, Hartwimmer J, Hauer A, Kaliebe T, Schopohl J, Stalla GK et al (1986). Corticotropin-releasing factor (CRF): stimulation in normal controls and in patients with Cushing's syndrome. Psychoneuroendocrinology 11: 49-60.

Nikolarakis K, Pfeiffer A, Stalla GK, Herz A (1987). The role of CRF in the release of ACTH by opiate agonists and antagonists in rats. Brain Res 421: 373-376.

O'Malley SS, Krishnan-Sarin S, Farren C, Sinha R, Kreek MJ (2002). Naltrexone decreases craving and alcohol self-administration in alcohol-dependent subjects and activates the hypothalamo-pituitary-adrenocortical axis. Psychopharmacology 160: 19-29.

Orth DN, Jackson RV, DeCherney GS, DeBold CR, Alexander AN, Island DP et al (1983). Effect of synthetic ovine corticotropinreleasing factor dose response of plasma adrenocorticotropin and cortisol. J Clin Invest 71: 587-595.

Plotsky PM, Meaney MJ (1993). Early, postnatal experience alters hypothalamic corticotropin-releasing factor (CRF) mRNA, median eminence CRF content and stress-induced release in adult rats. Brain Res Mol Brain Res 18: 195-200.

Radulovic J, Ruhmann A, Liepold T, Spiess J (1999). Modulation of learning and anxiety by corticotropin-releasing factor (CRF) and stress: differential roles of CRF receptors 1 and 2. J Neurosci 19: 5016-5025.

Richter RM, Pich EM, Koob GF, Weiss F (1995). Sensitization of cocaine-stimulated increase in extracellular levels of corticotropin-releasing factor from the rat amygdala after repeated administration as determined by intracranial microdialysis. Neurosci Lett 187: 169-172.

Richter RM, Weiss F (1999). In vivo CRF release in rat amygdala is increased during cocaine withdrawal in self-administering rats. Synapse 32: 254-261.

Sander T, Gscheidel N, Wendel B, Samochowiec J, Smolka M, Rommelspacher $\mathrm{H}$ et al (1998). Human mu-opioid receptor variation and alcohol dependence. Alcohol Clin Exp Res 22: 2108-2110.

Saphier PW, Faria M, Grossman A, Coy DH, Besser GM, Hodson B et al (1992). A comparison of the clearance of ovine and human corticotrophin-releasing hormone $(\mathrm{CRH})$ in man and sheep: a possible role for CRH-binding protein. J Endocrinol 133: 487495.

Sarnyai Z, Shaham Y, Heinrichs SC (2001). The role of corticotropin-releasing factor in drug addiction. Pharmacol Rev 53: 209-243.

Schluger JH, Borg L, Ho A, Kreek MJ (2001). Altered HPA axis responsivity to metyrapone testing in methadone maintained former heroin addicts with ongoing cocaine addiction. Neuropsychopharmacology 24: 568-575.

Schluger JH, Ho A, Borg L, Porter M, Maniar S, Gunduz M et al (1998). Nalmefene causes greater hypothalamic-pituitary-adrenal axis activation than naloxone in normal volunteers: implications for the treatment of alcoholism. Alcohol Clin Exp Res 22: 1430-1436.

Schuckit MA, Edenberg HJ, Kalmijn J, Flury L, Smith TL, Reich T et al (2001). A genome-wide search for genes that relate to a low level of response to alcohol. Alcohol Clin Exp Res 25: 323-329.

Schurmeyer TH, Avgerinos PC, Gold PW, Gallucci WT, Tomai TP, Cutler Jr GB et al (1984). Human corticotropin-releasing factor in man: pharmacokinetic properties and dose-response of plasma adrenocorticotropin and cortisol secretion. J Clin Endocrinol Metab 59: 1103-1108.

Shaham Y, Erb S, Leung S, Buczek Y, Stewart J (1998). CP-154,526, a selective, non-peptide antagonist of the corticotropin-releasing factor 1 receptor attenuates stress-induced relapse to drug seeking in cocaine- and heroin-trained rats. Psychopharmacology (Berl) 137: 184-190.

Shaham Y, Funk D, Erb S, Brown TJ, Walker CD, Stewart J (1997). Corticotropin-releasing factor, but not corticosterone, is involved in stress-induced relapse to heroin-seeking in rats. $J$ Neurosci 17: 2605-2614.

Smith GW, Aubry JM, Dellu F, Contarino A, Bilezikjian LM, Gold LH et al (1998). Corticotropin releasing factor receptor 1deficient mice display decreased anxiety, impaired stress response, and aberrant neuroendocrine development. Neuron 20: $1093-1102$.

Stimmel B, Kreek MJ (1975). Dependence, tolerance and withdrawal. In: Stimmel B (ed). Heroin Dependency: Medical, Economic and Social Aspects. Stratton Intercontinental Medical Book Corp.: New York. pp 88-97.

Sutton RE, Koob GF, Le Moal M, Rivier J, Vale W (1982). Corticotropin releasing factor produces behavioural activation in rats. Nature 297: 331-333.

Szeto CY, Tang NL, Lee DT, Stadlin A (2001). Association between $\mathrm{mu}$ opioid receptor gene polymorphisms and Chinese heroin addicts. Neuroreport 12: 1103-1106.

Timpl P, Spanagel R, Sillaber I, Kresse A, Reul JM, Stalla GK et al (1998). Impaired stress response and reduced anxiety in mice lacking a functional corticotropin-releasing hormone receptor 1. Nat Genet 19: 162-166.

Vale W, Spiess J, Rivier C, Rivier J (1981). Characterization of a 41residue ovine hypothalamic peptide that stimulates secretion of corticotropin and beta-endorphin. Science 213: 1394-1397.

Volavka J, Bauman J, Pevnick J, Reker D, James B, Cho D (1980). Short-term hormonal effects of naloxone in man. Psychoneuroendocrinology 5: 225-234. 
Volavka J, Cho D, Mallya A, Bauman J (1979). Naloxone increases ACTH and cortisol levels in man. N Engl J Med 300: 1056-1057. von Bardeleben U, Heuser I, Holsboer F (1989). Human CRH stimulation response during acute withdrawal and after medium-term abstention from alcohol abuse. Psychoneuroendocrinology 14: 441-449.

Waltman C, McCaul ME, Wand GS (1994). Adrenocorticotropin responses following administration of ethanol and ovine corticotropin-releasing hormone in the sons of alcoholics and control subjects. Alcohol Clin Exp Res 18: 826-830.

Wand GS, Mangold D, El Deiry S, McCaul ME, Hoover D (1998). Family history of alcoholism and hypothalamic opioidergic activity. Arch Gen Psychiatry 55: 1114-1119.

Wand GS, McCaul M, Yang X, Reynolds J, Gotjen D, Lee S et al (2002). The mu-opioid receptor gene polymorphism (A118G) alters HPA axis activation induced by opioid receptor blockade. Neuropsychopharmacology 26: 106-114.

Weninger SC, Dunn AJ, Muglia LJ, Dikkes P, Miczek KA, Swiergiel $\mathrm{AH}$ et al (1999). Stress-induced behaviors require the corticotropin-releasing hormone $(\mathrm{CRH})$ receptor, but not CRH. Proc Natl Acad Sci USA 96: 8283-8288.

Zhou Y, Franck J, Spangler R, Maggos CE, Ho A, Kreek MJ (2000). Reduced hypothalamic POMC and anterior pituitary CRF1

receptor mRNA levels after acute, but not chronic, daily 'binge' intragastric alcohol administration. Alcohol Clin Exp Res 24: $1575-1582$.

Zhou Y, Spangler R, LaForge KS, Maggos CE, Ho A, Kreek MJ (1996a). Corticotropin-releasing factor and type 1 corticotropin-releasing factor receptor messenger RNAs in rat brain and pituitary during 'binge'-pattern cocaine administration and chronic withdrawal. J Pharmacol Exp Ther 279: 351-358.

Zhou Y, Spangler R, Maggos CE, LaForge KS, Ho A, Kreek MJ (1996b). Steady-state methadone in rats does not change mRNA levels of corticotropin-releasing factor, its pituitary receptor or proopiomelanocortin. Eur J Pharmacol 315: 31-35.

Zhou Y, Spangler R, Maggos CE, Wang XM, Han JS, Ho A et al (1999). Hypothalamic-pituitary-adrenal activity and pro-opiomelanocortin mRNA levels in the hypothalamus and pituitary of the rat are differentially modulated by acute intermittent morphine with or without water restriction stress. J Endocrinol 163: 261-267.

Zobel AW, Yassouridis A, Frieboes RM, Holsboer F (1999). Prediction of medium-term outcome by cortisol response to the combined dexamethasone-CRH test in patients with remitted depression. Am J Psychiatry 156: 949-951. 